\title{
Can topdressing with salt increase oversowing success and pasture quality on steep, south facing slopes in hill country pastures?
}

\author{
B.J. GILLESPIE, R.J. LUCAS, D.J. MOOT and G.R. EDWARDS \\ Agriculture Group, Agriculture and Life Sciences Division, Field Service Centre, Lincoln University, Lincoln 7647 \\ edwardsg@lincoln.ac.nz
}

\begin{abstract}
Two experiments were conducted in sodium deficient $(<0.03 \% \mathrm{Na}$ in $\mathrm{DM})$ pastures on steep, south facing slopes at Mt Grand, Hawea, Central Otago (600 m.a.s.l), to determine the effect of the application of coarse salt $(\mathrm{NaCl})$ fertiliser on pasture composition and establishment of oversown seeds. In Experiment 1 , factorial combinations of salt $(0,150 \mathrm{~kg} \mathrm{NaCl} / \mathrm{ha}), \mathrm{N}(0,100 \mathrm{~kg}$ $\mathrm{N} / \mathrm{ha}$ as urea) and sulphur superphosphate $(0,500 \mathrm{~kg} /$ ha) fertilisers were applied to $30 \times 8 \mathrm{~m}$ plots in early December 2003. Balansa clover (10 kg seed/ha) and subterranean clover $(10 \mathrm{~kg} / \mathrm{ha})$ seeds were oversown into each plot in March 2004. Plots where salt was applied were grazed intensively by Merino ewes immediately after salt application creating up to $50 \%$ bare ground. In December 2004, pastures where salt had been applied one year earlier were shorter, had a lower percentage of white clover and a higher percentage of bare ground and balansa clover. In Experiment 2, factorial combinations of salt fertiliser $(0,100 \mathrm{~kg} \mathrm{NaCl} / \mathrm{ha})$ and seed (no seed, mixture of Caucasian clover $(10 \mathrm{~kg} / \mathrm{ha})$, Lotus pendunculatus $(2 \mathrm{~kg} / \mathrm{ha})$ and plantain $(2 \mathrm{~kg} / \mathrm{ha}))$ were applied together to $5 \times 10 \mathrm{~m}$ plots in September 2004. In April 2005, pastures where salt was applied were shorter, had fewer grass seedheads, a lower percentage of resident grasses and litter but a higher percentage of bare ground and plantain. There were more seedlings of plantain where salt was $\left(6.5\right.$ seedlings $\left./ \mathrm{m}^{2}\right)$ than where it was not applied (1.1 seedlings $\left./ \mathrm{m}^{2}\right)$. This small plot work indicates that salt fertiliser application to Na-deficient herbage can enhance grazing intensity. By creating soil disturbance and reducing competition from resident grasses, salt application increased the establishment of oversown seeds of plantain and balansa clover. Establishment of the slow growing species (Caucasian clover, lotus) and the large seeded subterranean clover appeared to be unsuccessful under the conditions of the experiments. Salt application is a tool for pasture management and improvement in the hill/high country that could be used together with other methods such as herbicides, seeding, sub-division, grazing management and fertiliser.
\end{abstract}

Keywords: grazing, sodium, oversowing, hill country

\section{Introduction}

The pasture quality of steep, south-facing slopes in the hill and high country is often poor, with considerable, tall, rank, laxly-grazed grass, a high proportion of dead material and a low proportion of pasture legume. The establishment of seeds of legumes and herbs oversown onto these sites to improve pasture quality is often negligible due to insufficient grazing to remove the tall competing grass (e.g. cocksfoot, browntop, tall oat grass) vegetation that can inhibit germination and seedling survival (Lambert et al. 1985; Awan et al. 1993).

Previous survey work indicates that large areas of inland South Island, New Zealand, have pasture sodium (Na) levels in herbage DM less than the $0.07 \% \mathrm{Na}$ required for a maintenance diet of sheep (Towers \& Smith 1983; Aspinall et al. 2004). Moreover, Merino sheep are strongly attracted to, and graze intensively, in areas of $\mathrm{Na}$-deficient pasture that have been fertilised with salt $(\mathrm{NaCl})$ (Aspinall et al. 2004). These findings raise the possibility of improving pasture quality by using the preference of sheep for applied salt as a tool to intensify grazing and treading on the slopes of Na-deficient inland properties that normally have poor grazing utilisation.

The hypothesis tested in this study was that the destruction of dead material and greater control of grass growth that is achieved with more intense grazing and trampling following salt application would allow existing legumes to flourish and provide conditions that are more conducive to the establishment of oversown seeds.

\section{Materials and methods \\ Study site}

Two experiments were conducted on Na-deficient $(<0.03 \% \mathrm{Na}$ in herbage DM) pasture on south facing slopes (20-35 slope; $540-610 \mathrm{~m}$ a.s.l) at Mt Grand Station, $2 \mathrm{~km}$ south east of Hawea Flat, Central Otago. Mt Grand is $150 \mathrm{~km}$ from the east coast and $85 \mathrm{~km}$ from the west coast, with mean annual rainfall at $600 \mathrm{~m}$ a.s. 1 of $700 \mathrm{~mm}$. The south-facing hill pastures were dominated by three grass species, cocksfoot, tall oat-grass and sweet vernal, with white clover and suckling clover the dominant legumes. Both experiments were located on Arrow steepland soils (Blakemore 1968). Soil samples taken from each site before experiments began and analysed with a MAF quick test showed: Experiment 1, $\mathrm{pH}=5.6$, Olsen $\mathrm{P}=16$, Sulphate- $\mathrm{S}=10$ m.e. $/ 100 \mathrm{~g}$, Na $=2.0$ m.e. $/ 100 \mathrm{~g}$; and Experiment $2, \mathrm{pH}=6.0$, Olsen $\mathrm{P}=$ 19 , Sulphate-S $=14$ m.e. $/ 100 \mathrm{~g}, \mathrm{Na}=2.0$ m.e. $/ 100 \mathrm{~g}$. The experiments were carried out in three paddocks where 
no salt (neither fertiliser nor blocks) had previously been used.

Oversowing experiments were conducted with five species (balansa clover Trifolium michelianum, subterranean clover T. subterraneum, Caucasian clover T. ambiguum, lotus Lotus pendunculatus and plantain Plantago lanceolata) that may be agronomically suitable in the Mt Grand environment (Moorhead et al. 1994; Stewart \& Charlton 2003) but which are potentially difficult to establish.

\section{Experiment 1}

This seed oversowing study is a continuation of a fertiliser project established in 2003, with initial results reported by Aspinall et al. (2004). The experimental design was three replicates of a $2 \times 2 \times 2$ factorial (eight treatments) laid out in a randomised block design. Two replicates were laid out within Watties ( $80 \mathrm{ha}$ ) and one in Broad Leaf (185 ha) paddocks. The three factors were $\mathrm{Na}(0$ and $150 \mathrm{~kg} \mathrm{NaCl} / \mathrm{ha}$ as coarse $1-4 \mathrm{~mm}$ granules), $\mathrm{N}(0$ and $100 \mathrm{~kg} \mathrm{~N} / \mathrm{ha}$ as urea) and $\mathrm{P}+\mathrm{S}(0$ and $500 \mathrm{~kg}$ / ha as $19 \%$ sulphur superphosphate). All fertilisers were broadcast by hand on 9 December 2003. Each block consisted of eight $30 \times 8 \mathrm{~m}$ plots laid out across the slope, with a $30 \times 8 \mathrm{~m}$ buffer between each plot. To test the residual effects of the fertiliser treatments on oversowing success, half of each plot was oversown with a mixture of balansa (cv. Bolta) and subterranean (Woogenellup) clover at $10 \mathrm{~kg} / \mathrm{ha}$ per species on 3 March 2004. Lactating Merino ewes were present during the application of fertilisers and within 2 days their intensive grazing and trampling resulted in bare ground approaching $50 \%$ versus $20 \%$ where no salt was applied. Merino hoggets were present when seed was spread but grazing intensity on all plots was low. Rainfall in autumn after seed spread was $70 \mathrm{~mm}$ in March 2004 but only $13 \mathrm{~mm}$ in April 2004.

Pasture ground cover of all species was visually estimated in ten $0.1 \mathrm{~m}^{2}$ quadrats in each plot on 1-3 December 2004. To provide an indication of grazing intensity, pasture height was measured with a sward stick in 50 locations per plot on 11 November 2004, and 21 January and 14 April 2005. To provide a more precise estimate of balansa clover seedling recruitment following seed application in March 2004, balansa clover inflorescences were counted in five $0.1 \mathrm{~m}^{2}$ quadrats in each plot on 28 January 2005.

\section{Experiment 2}

The experimental design was six replicates of a $2 \times 2$ factorial (four treatments) laid out in a randomised block design. All replicates were within Valley (60 ha) paddock. The two factors were $\mathrm{Na}(0$ and $100 \mathrm{~kg} \mathrm{NaCl} / \mathrm{ha}$ as 0.5 $1 \mathrm{~mm}$ fine granules) and oversown seed (no seed or a mixture of $10 \mathrm{~kg} / \mathrm{ha}$ Caucasian clover, cv. Endura, $2 \mathrm{~kg} /$ ha Lotus pendunculatus $\mathrm{cv}$. Sunrise and $2 \mathrm{~kg} /$ ha plantain, cv. Tonic). Both legumes were freshly inoculated with their specific rhizobium strains. Seed and fertilisers were broadcast sown together by hand on 27 September 2004. Each block consisted of four $5 \times 10 \mathrm{~m}$ plots laid out across the slope, with a $10 \times 10 \mathrm{~m}$ buffer between each plot. Lactating Merino ewes (280) were present when salt and seed were applied and grazed the salt plots more intensively than elsewhere. Rainfall of $48 \mathrm{~mm}$ in September 2004 and $47 \mathrm{~mm}$ in October 2004 were less than the average $65 \mathrm{~mm}$ per month; but $70 \mathrm{~mm}$ in November 2004 and $155 \mathrm{~mm}$ in December 2004 exceeded expectations.

Pasture ground cover of all species was visually estimated and seedlings of sown species were counted in ten $0.1 \mathrm{~m}^{2}$ quadrats in each plot on 14 April 2005. To provide an indication of grazing intensity, pasture height was measured with a sward stick in 50 locations per plot on 25 November 2004 and 28 January 2005, and seed heads of cocksfoot, tall oat grass and sweet vernal were counted in six $0.1 \mathrm{~m}^{2}$ quadrats in each plot on 31 November 2004 and 16 April 2005.

Data from both experiments were analysed by factorial ANOVA. Percentage composition and count data were arcsine square-root transformed and square-root transformed, respectively, before ANOVA.

\section{Results \\ Experiment 1}

When sampled 12 months after the start of the experiment, salt application resulted in pastures that were shorter and with a lower percentage of white clover and resident annual legumes than where no salt was applied. Salt application also resulted in pastures with a higher percentage of bare ground, balansa clover and dicot weeds than where no salt was applied (Table 1). There were more balansa clover inflorescences where salt was applied. Urea application resulted in pastures with a higher percentage of resident grasses and a lower percentage of balansa and resident annual legumes than where no urea was applied (Table 1). Superphosphate application resulted in a higher percentage of white clover (Table 1). There were no significant interactions between salt, nitrogen and superphosphate application.

\section{Experiment 2}

Salt application resulted in pastures that were shorter, had fewer grass seed heads and a lower percentage of resident grasses and litter than where no salt was applied (Table 2). The percentage of bare ground and plantain was greater where salt was applied. Seedlings of plantain, but not Caucasian clover or lotus, were found in counts conducted on 14 April 2004. Plantain seedlings were 
Table 1 Pasture composition (\%) on 1 December 2004, pasture height $(\mathrm{cm})$, and balansa inflorescences $/ \mathrm{m}^{2}$ after the application of salt $(\mathrm{NaCl})$, nitrogen (urea) and sulphur superphosphate on 9 December 2003. Significance of main effects denoted by ${ }^{*} \mathrm{P}<0.05$, ${ }^{* *} \mathrm{P}<0.01$, ns non significant.

\begin{tabular}{|c|c|c|c|c|c|c|c|c|c|}
\hline & \multicolumn{2}{|c|}{$\begin{array}{c}\text { Salt } \\
(\mathrm{kg} / \mathrm{ha})\end{array}$} & & \multicolumn{2}{|c|}{$\begin{array}{l}\text { Nitrogen) } \\
(\mathrm{kg} / \mathrm{ha})\end{array}$} & & \multicolumn{2}{|c|}{$\begin{array}{l}\text { Superphosphate } \\
(\mathrm{kg} / \mathrm{ha})\end{array}$} & \\
\hline & 0 & 150 & & 0 & 100 & & 0 & 500 & \\
\hline \multicolumn{10}{|l|}{ Pasture composition (\%) } \\
\hline Resident grasses & 53.0 & 53.0 & ns & 50.1 & 56.0 & * & 54.8 & 51.3 & ns \\
\hline White clover & 14.3 & 10.9 & $\star \star *$ & 12.3 & 12.8 & ns & 11.5 & 13.6 & * \\
\hline Subterranean clover & 0.8 & 1.0 & ns & 1.1 & 0.7 & ns & 1.0 & 0.8 & ns \\
\hline Balansa clover & 1.4 & 2.3 & * & 2.3 & 1.3 & * & 1.7 & 2.0 & ns \\
\hline Resident annual legumes & 12.1 & 10.5 & * & 12.4 & 10.2 & * & 11.6 & 11.0 & ns \\
\hline Litter & 9.5 & 8.0 & ns & 8.9 & 8.6 & ns & 8.8 & 8.6 & ns \\
\hline Dicot weeds & 4.5 & 5.8 & * & 5.3 & 5.0 & ns & 5.3 & 5.0 & ns \\
\hline Bare ground & 4.4 & 8.5 & * & 7.5 & 5.4 & ns & 5.2 & 7.7 & ns \\
\hline \multicolumn{10}{|l|}{ Pasture height (cm) } \\
\hline 11 Nov 04 & 10.7 & 8.9 & * & 9.6 & 10.1 & ns & 9.8 & 9.8 & ns \\
\hline 21 Jan 05 & 19.4 & 16.4 & * & 17.4 & 18.6 & ns & 18.9 & 16.9 & ns \\
\hline 14 Apr 05 & 20.1 & 19.0 & ns & 18.4 & 20.7 & ns & 20.9 & 18.1 & ns \\
\hline \multicolumn{10}{|c|}{ Balansa inflorescences $/ \mathrm{m}^{2}$} \\
\hline 28 Jan 2005 & 7.1 & 25.3 & * & 22.1 & 9.6 & ns & 10.7 & 21.2 & ns \\
\hline
\end{tabular}

Table 2 Pasture composition (\%) on 14 April 2005, pasture height (cm), and seedheads $/ \mathrm{m}^{2}$ after the application of salt (100 kg NaCl/ha) and seed (plantain, Caucasian clover and lotus) on 27 September 2004. Data are means averaged across plots where seed was and was not sown. Significance of main effects denoted by * $\mathrm{P}<0.05$, ${ }^{*} \mathrm{P}<0.01$, ns non significant.

\begin{tabular}{|c|c|c|c|c|}
\hline & & \multicolumn{2}{|c|}{ Salt (kg/ha) } & \\
\hline & & 0 & 100 & \\
\hline \multicolumn{5}{|c|}{ Pasture composition (\%) } \\
\hline \multicolumn{2}{|c|}{ Resident grasses } & 62.5 & 48.5 & ** \\
\hline \multicolumn{2}{|l|}{ White clover } & 9.4 & 12.2 & ns \\
\hline \multicolumn{2}{|l|}{ Annual legumes } & 1.0 & 1.5 & ns \\
\hline \multicolumn{2}{|l|}{ Dicot weeds } & 3.3 & 3.7 & ns \\
\hline \multicolumn{2}{|l|}{ Plantain } & 0.1 & 2.3 & * \\
\hline \multicolumn{2}{|l|}{ Litter } & 19.1 & 9.9 & ** \\
\hline \multicolumn{2}{|l|}{ Bare ground } & 4.6 & 22.4 & ** \\
\hline \multicolumn{5}{|c|}{ Pasture height $(\mathrm{cm})$} \\
\hline \multirow{2}{*}{\multicolumn{2}{|c|}{$\begin{array}{l}25 \text { Nov } 04 \\
28 \text { Jan } 05\end{array}$}} & 10.9 & 5.8 & * \\
\hline & & 23.6 & 6.8 & * \\
\hline \multicolumn{5}{|l|}{ Seedheads $/ \mathrm{m}^{2}$} \\
\hline \multirow{3}{*}{31 Nov 04} & Cocksfoot & 43 & 10 & ** \\
\hline & Tall oat & 17 & 3 & * \\
\hline & Sweet vernal & 315 & 89 & ** \\
\hline \multirow[t]{3}{*}{16 Apr 05} & Cocksfoot & 65 & 1 & ** \\
\hline & Tall oat & 52 & 1 & ** \\
\hline & Sweet vernal & 117 & 10 & ** \\
\hline
\end{tabular}

only found on sown plots, with the number of plantain seedlings greater where salt was applied (6.5 seedlings/ $\left.\mathrm{m}^{2}\right)$ than where it was not applied $\left(1.1\right.$ seedlings $\left./ \mathrm{m}^{2}\right)$ (salt $\mathrm{x}$ seed interaction, $\mathrm{P}<0.05$ ).

\section{Discussion}

Seedling recruitment of legumes and herbs from natural reseeding or following oversowing in pastures is often limited, particularly in the hill and high country, due to insufficient grazing to remove competing vegetation (Lambert et al. 1985; Edwards et al. 2005). This study provided some evidence that this limitation could be overcome by the application of salt to enhance grazing intensity. Both balansa clover in Experiment 1 and plantain in Experiment 2 showed greater seedling establishment where salt was applied. The most likely explanation for 
the increased establishment with salt application is the greater percentage of bare ground and reduced competition from resident grass species (cocksfoot and tall oat-grass) associated with more intense grazing. This may have enhanced either germination or seedling survival, although measurements were not taken to distinguish between these two processes in this study. Previous studies have shown that seedling establishment of plantain increases as the proportion of bare ground increases (Edwards et al. 2005). The result is also consistent with previous hill and high country work that shows intensive 'hoof and tooth' grazing opens up pastures and enhances establishment (MacFarlane \& Bonish 1986; Lambert et al. 1985). Thus, it appears that the application of salt increased stocking rate within a specific area of a large block without the requirement for fencing or shepherding stock, and so may be a tool that could be used together with other methods such as herbicides, subdivision and fertilisers to improve oversowing success.

No seedlings of lotus or Caucasian clover were found and there was no detectable increase in subterranean clover cover following oversowing. The poor establishment of lotus and Caucasian clover is consistent with previous studies (Brock \& Charlton 1978; Moorhead et al. 1994; Black et al. 2002), where establishment is slow, even under cultivated conditions where competition is minimised. The poor establishment does not reflect low seed viability as this was $>87 \%$ in all species in laboratory tests. Alternative explanations include the high thermal time requirements for seedling development of these species (Black et al. 2002), desiccation from lack of cover and poor radicle entry due to seeds remaining on the soil surface (Campbell \& Swain 1973). Drilling has been shown to significantly increase Caucasian clover seedling establishment above that of oversowing (Moorhead et al. 1994), while subterranean clover seeds have higher germination when buried (Yates 1957).

Aspinall et al. (2004) reported small areas treated with $100 \mathrm{~kg} \mathrm{NaCl} / \mathrm{ha}$ at the start of Experiment 1 attracted extreme grazing and trampling by Merino ewes, with up to $50 \%$ bare ground created within 1 week of salt application. Similar responses where also observed in Experiment 2, where sheep were observed grazing intensively on plots within $48 \mathrm{~h}$ of salt application; pastures remained shorter over the next 7 months and had fewer grass seed heads. Measurements reported here from Experiment 1 indicated that the effects of salt application on grazing preference may be long lasting, with bare ground percentage higher and pasture height shorter 12 months after salt application. This sustained preference for areas where salt was applied may reflect two processes. First, it may be due to the preference of sheep for herbage with elevated $\mathrm{Na}$ content. Herbage $\mathrm{Na}$ was not measured after 12 months in Experiment 1. However, in a parallel experiment (Gillespie 2006) at the same site in which $150 \mathrm{~kg} / \mathrm{ha}$ of salt was spread at the same time as in Experiment 1, the Na content of cocksfoot herbage 12 months after salt application was greater where salt was applied $(0.08 \%$ of DM) than where it was not applied $(0.03 \% \mathrm{DM})$. Second, it may be due to preference for short vegetative material lacking dead and reproductive material that was created by the initial salt application and intensive grazing.

The percentage of white clover in the pasture was lower where salt was applied in Experiment 1 and unaffected by salt application in Experiment 2. Thus, there was no evidence to support the idea that the shorter pasture, lower percentage of resident grasses and higher percentage of bare ground resulting from salt application allowed white clover stolons to expand into vacant space and increase in abundance. The observed response could be due to treading damage of stolons soon after salt application combined with preferential grazing of short developing clover stolons.

The effect of nitrogen and superphosphate fertiliser on the vegetation was small compared to salt application. The initial nitrogen fertiliser boost to grass growth remained in Experiment 1. The 6\% extra ground cover of resident grasses in the nitrogen-fertilised plots may have caused the small reduction in annual clover cover. While there was a small increase in white clover cover with the addition of sulphur superphosphate, there was no response in the annual clovers.

\section{ACKNOWLEDGEMENTS}

We thank: Dominion Salt Ltd and the Miss E A, Hellaby Indigenous Grassland Trust for financial support for the project; Gordon Meikle, Mt Grand Farm Manager, and Tony Whatman, Lincoln University Director of Farms for their advice and technical support with stock.

\section{REFERENCES}

Awan, M.H.; Kemp, P.D.; Choudhary, M.A.; Barker, D.J. 1993. Pasture legume establishment from oversowing in drought-prone hill country. Proceedings of the New Zealand Grassland Association 55: 101-104.

Aspinall, R.; Mandaluniz, N.; Hight, L.J.; Lucas, R.J. 2004. Sodium deficiency in Canterbury and Central Otago sheep pastures. Proceedings of the New Zealand Grassland Association 66: 227-232.

Blakemore, L.C. 1968. General survey of the soils of South Island, New Zealand. In: New Zealand Soil Bureau Bulletin 27.

Black, A.D.; Moot, D.J.; Lucas, R.J. 2002. Seedling development and growth of white clover, Caucasian clover and perennial ryegrass grown in field and 
controlled environments. Proceedings of New Zealand Grassland Association 64: 197-204.

Brock, J.L.; Charlton, J.F.L. 1978. Lotus pedunculatus establishment in intensive farming. Proceedings of New Zealand Grassland Association 39: 121-129.

Campbell, M.H.; Swain, F.G. 1973. Effect of strength, tilth and heterogeneity of soil surface on the radicleentry of surface-sown seeds. Journal of the British Grasslands Society 28: 41-50.

Edwards, G.R.; Hay, M.J.M.; Brock, J.L. 2005 Seedling recruitment dynamics of forage and weed species under continuous and rotational sheep grazing in a temperate New Zealand pasture. Grass and Forage Science 60: 186-199.

Gillespie, B.J. 2006. Modifying merino grazing and pasture composition in the high country by salt application. MAgSci Thesis. Lincoln University.

Lambert, M.G.; Rhodes, A.P.; Barker, D.J.; Bircham, J.S. 1985. Establishing and managing improved plants in hill country. Using herbage cultivars. Grassland Research and Practice Series No. 3: 31-34.

Macfarlane, M.J.; Bonish, P.M. 1986. Oversowing white clover into cleared and unimproved North Island hill country. The role of management, fertiliser, inoculation, pelleting and resident rhizobia. Proceedings of New Zealand Grassland Association 47: 43-51.

Moorhead, A.J.E.; White, J.G.H.; Jarvis, P.; Lucas, R.J.; Sedcole, J.R. 1994. Effect of sowing method and fertiliser application on establishment and first season growth of Caucasian clover. Proceedings of the New Zealand Grassland Association 56: 91-95.

Stewart, A.V.; Charlton, J.F.L. 2003. Pasture and forage plants for New Zealand. New Zealand Grassland Association and New Zealand Grassland Trust. Grassland Research and Practice Series No 8. 96 pp.

Towers, N. R.; and Smith, G. S. 1983. Sodium. The mineral requirements of grazing ruminants. New Zealand Society of Animal Production. pp 115-124 In: Occasional Publication No. 9.

Yates, J.J. 1957. Seed-setting in subterranean clover (Trifolium subterraneum L.). 1. The importance of the micro-environment. Australian Journal of Agricultural Research 8: 433-443. 